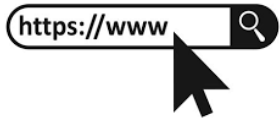

DOI: https://doi.org/10.18485/ijdrm.2021.3.2.1

Research article

\title{
METHODOLOGY FOR BUILDING AUTOMATED SYSTEMS FOR MONITORING ENGINEERING (LOAD-BEARING) STRUCTURES, AND NATURAL HAZARDS TO ENSURE COMPREHENSIVE SAFETY OF BUILDINGS AND CONSTRUCTIONS
}

\author{
Kachanov Sergey \\ Deputy Director of the Russian-Serbian Humanitarian Center, Niš, Serbia. \\ *Correspondence: kacanov.sa@ihc.rs \\ Received: 6 October 2021; Accepted: 10 December 2020; Published: 31 December 2021
}

\begin{abstract}
The load-bearing structures of buildings and constructions (further on referred to as 'facilities') are subject to wear-caused loss of operability. Exploitation of facilities with damaged construction elements may lead to emergencies, which are likely to cause loss of life.The article describes a methodology for automated monitoring of engineering (load-bearing) structures and natural hazards to ensure comprehensive safety of buildings and constructions.
\end{abstract}

Keywords: automated monitoring systems, safety of buildings and constructions, assessment of technical condition of facility load-bearing structures, emergencies.

\section{Introduction}

The load-bearing structures of buildings and constructions (further on referred to as 'facilities') are subject to wear-caused loss of operability. Exploitation of facilities with damaged construction elements may lead to emergencies, which are likely to cause loss of life. This is confirmed by unexpected collapses of facility construction elements in Russia, Azerbaijan, Germany, Poland, and other countries, which resulted in extensive casualties (Ginzburg \& Khripushin, 2013, Ginzburg, Ryzhkova \& Skiba, 2014) (Figure 1). 


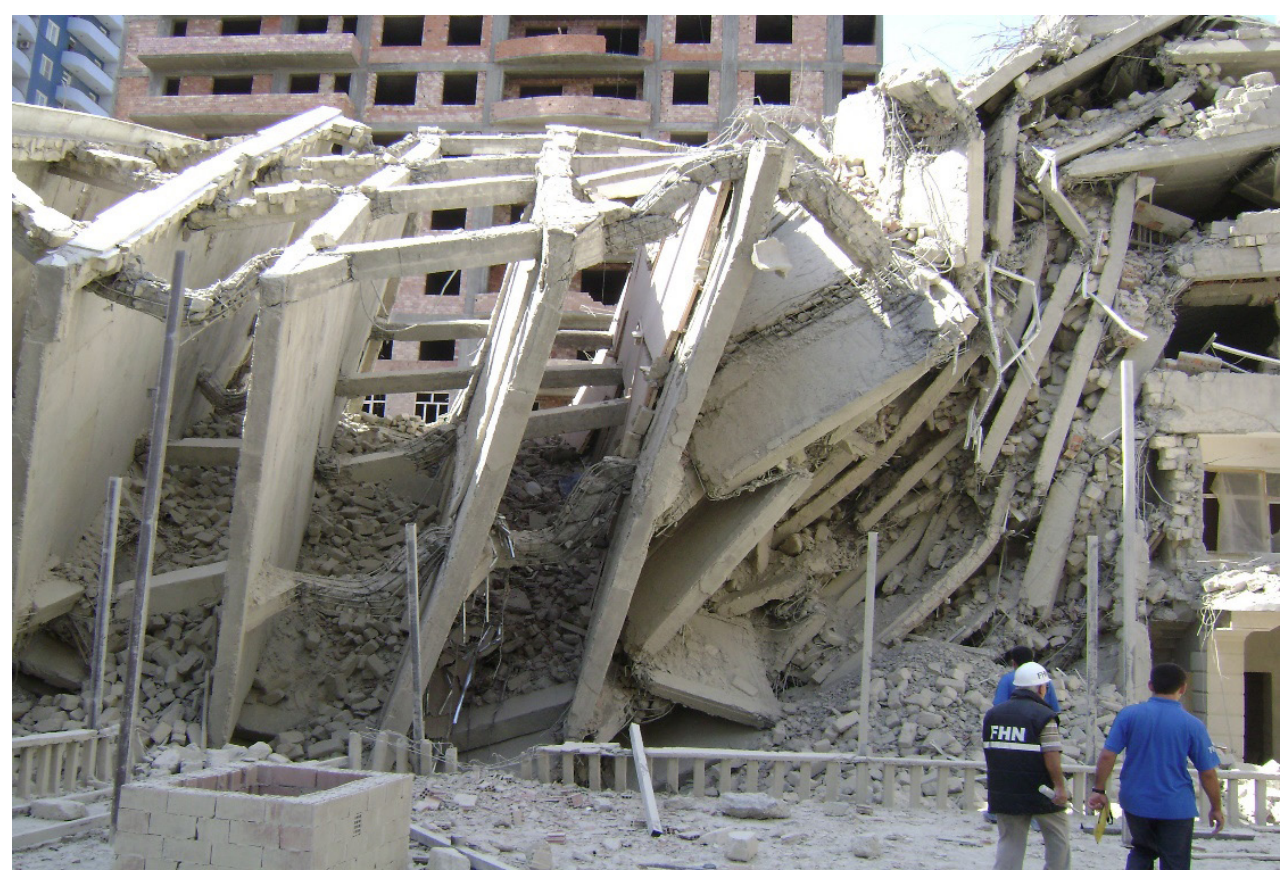

Figure 1. Suddenly Collapsed Building in Baku, 2007.

Various disasters have struck countries around the world in recent decades, with the frequency of such events significantly increasing, having a devastating impact on buildings and infrastructures, killing millions of people, and exposing the environment to growing dangers (Rico, 2019). Given the overall lack of awareness of such threats among the general public, it is required to engage in a variety of initiatives in order to positively improve the situation.

The assumption behind integrated natural disaster management is that people can perceive, identify, and assess a wide range of natural catastrophe risks (Cvetkovic \& Martinovic, 2021). The FGBU VNII GOChS (FTs), MGSU and a number of other agencies have jointly designed a unique technology for building an automated structured system for monitoring engineering (load-bearing) structures, and natural hazards (ESMS) to ensure comprehensive safety of buildings and constructions (Kachanov \& Nigmetov, 2008, Kachanov, Volkov \& Fatyhoy, 2009, Kachanov, Mahutov \&Taranov, 2010). The ESMS is designed for: timely automated remote notification of the emergency and dispatching services, management, and on-duty services of the facility under monitoring, on the condition of the facility's load-bearing structures and natural hazards, using the following criteria: 'normal condition', 'higher risk', 'emergency'; monitoring and documenting changes in the condition of the load-bearing structures and natural hazards caused by accumulated exploitation defects, which may lead the building or construction to an extreme condition mandating corresponding repairs or bringing the operation to a halt, throughout the whole facility operation period.

The ESMS is comprised by equipment for monitoring changes in the condition of foundations and engineering structures of buildings and constructions; engineering protection facilities, and also, if there is any corresponding hazard, for monitoring the areas of possible mudflows, mudslides and avalanches in the building or construction operation area (Volkov, Sedov, Chelyshkov \& Zinkov, 2010). It includes: ESMS servers, local servers and controllers; ESMS automated workstations (AW); data gathering and transferring network equipment; sensors monitoring changes in the condition of foundations and engineering structures of buildings and constructions; engineering protection facilities, and also areas of possible mudflows, mudslides and avalanches (Kachanov, Batyrev \& Volkov, 2011).

See Figure 2 for the ESMS algorithm. 

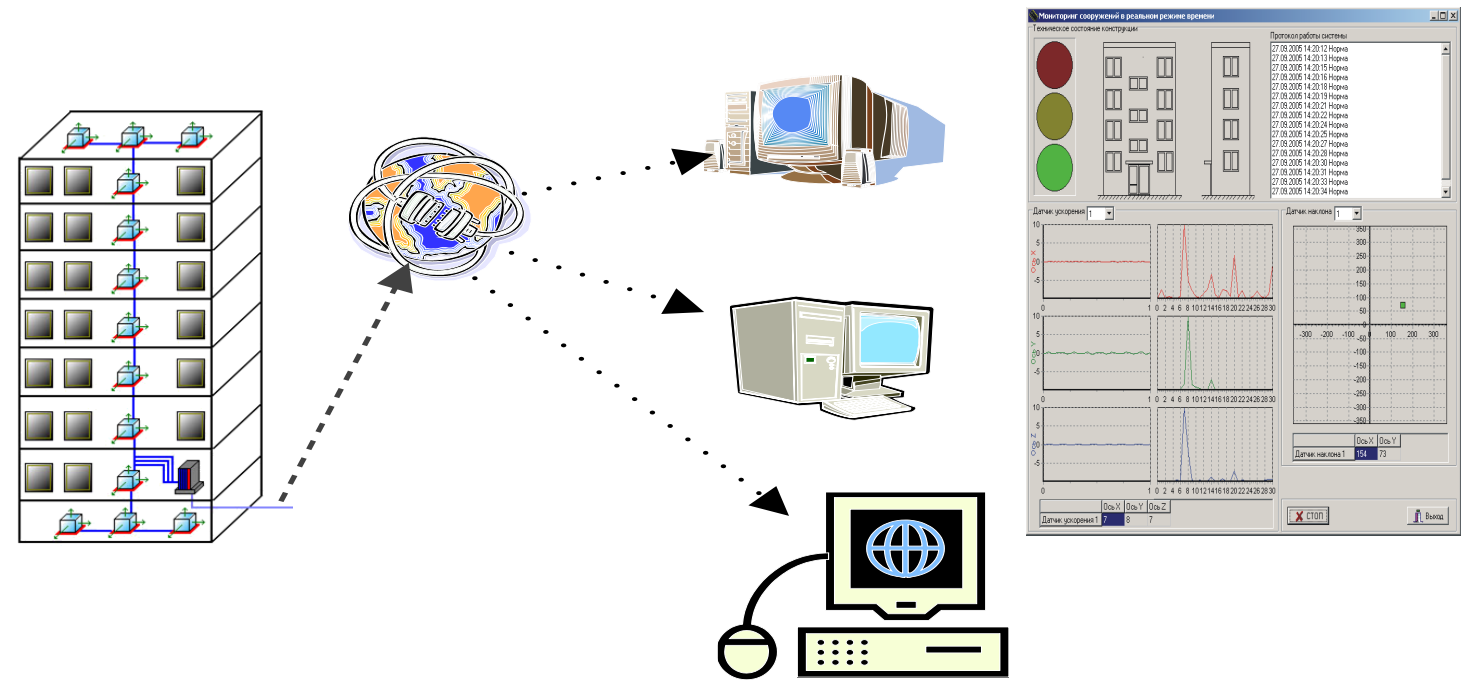

Figure 2. ESMS Algorithm.

The ESMS has the following functional subsystems (Kachanov, Batyrev \& Volkov, 2011): 1) the signaling monitoring subsystem, which continuously operates: to monitor the integral characteristics of the facility load-bearing structures in an automated real-time mode; to notify the facility operations control desk and the city emergency service personnel on the critical changes in the condition (deformed condition) of the facility structures in an automated real-time mode; 2 ) the intermittent monitoring subsystem, which is launched by notifications (incident, accident) coming from the signaling monitoring subsystem or under a regulation. In an automated mode it: assesses the technical condition of the facility load-bearing structures and issues recommendations for reinforcement (reconstruction); controls and adjusts (if necessary) the signaling subsystem.

ESMS installation is advisable for the following types of facilities: facilities constituting nuclear and/or radiation hazard (nuclear power plants, research reactors, fuel cycle facilities, temporary and long-time warehouses for nuclear fuel and radioactive waste), facilities using nuclear energy; for production, use, processing, generation, storage, transportation and disposal of hazardous materials in the volumes exceeding the limits under the Russian Federation Law; for chemical and other hazardous waste disposal and burial; having large warehouses for storage of oil and oil products (over 20,000 tonnes) and isothermal storage facilities for liquefied gases; for production of melts of ferrous and nonferrous materials and alloys based on these melts; for mining, minerals processing, subsoil operations, including companies performing subsoil and open-pit (mining depth over $150 \mathrm{~m}$ ) extraction and processing of solid minerals; using stationary cableways and funiculars; for production, generation or processing of liquid or solid materials with explosive features or prone to spontaneous decomposition with a possible explosion energy equal to 4.5 tonnes of TNT; power transmission lines and other grid facilities with the voltage of 330 kilovolts or more; space infrastructure facilities; airports and their infrastructure facilities; public railway system facilities; metros; sea ports excluding specialized sea ports for sports and pleasure boats maintenance; thermal power plants with the capacity of 150 megawatts and more; offshore oilfield facilities; mainline gas, oil and product pipelines; gas distribution system facilities using, storing or transporting natural gas or liquefied hydrocarbon gas; waterworks of class 1,2 and 3; large industrial facilities with more than 10,000 workers; capital construction facilities with the design documentation comprising at 
least one of the following features: height over 100 meters; flights over 100 meters; console over 20 meters; with depth of the subsoil part (in full or in part) more than 10 meters below the grade (ground) elevation; with constructions and construction systems, which have unconventional design methods applied to them to consider physical or geometric non-linear features or have specialized design methods developed for them; facilities with maximum design capacity of 500 people and more: entertainment, sports facilities, multifunctional office centers and shopping malls, health facilities, hotels; life-supporting facilities: units, warehouses, storage facilities, waterworks and engineering protection facilities and communications whose destruction (damage to) may disrupt the life of people (stop water, gas, heat, power supply, cause flooding, damage residential communities, cause failure of waste water and sewage water treatment facilities) resulting in an emergency.

ESMS has unique features and thus requires dedicated scientific and technical research. Firstly, the subsystem has to gather long-term, reliable and accurate information on the condition of load-bearing structures. This requirement stems from the fact that construction facilities, especially the unique ones, are designed for a long life totaling dozens and even hundreds of years and the accident-causing events feature very low probability of tenths and even thousandths of a percent.

It is advisable to highlight an important feature of the ESMS design calculations compared to the load-bearing structures design calculations. The design process has to ensure the structures reliability under the statistical uncertainty of the design parameters, which is often offset by establishing safety margins and redundancy of design models. While performing calculations for setting up an ESMS, including experimental research, one has to deal with a real structure and real loads, while the design models have to be adequate for a real construction operation. All the features mentioned require in-depth analysis of the results of theoretical and experimental research to project the behavior of structures in exploitation, which will help design a concept for a monitoring system and its technical implementation, design the parameters and criteria to assess the technical condition of the structures for decision-making concerning further exploitation (Kachanov, Volkov \& Fatyhoy, 2009, Kachanov, Batyrev \& Volkov, 2011).

The following tasks are to be performed to achieve the goal: a) to create a mathematical model of the load-bearing structures; b) to calibrate the model based on on-site experimental data to ensure its adequacy; c) to perform static calculations under normal construction exploitation conditions (based on standard loads) and extreme conditions (based on design loads) to identify and assess the parameters controlled by monitoring; $d$ ) to perform dynamic calculations - modal analysis and vibration-based diagnostics - to project and analyze corresponding experimental data; e) to perform dynamic calculations to identify typical damage scenarios and corresponding changes in the controlled parameters of the structures.

Let's consider a mathematical model for the roof of the Ice Sports Palace on the Khodynskoye Field in Moscow as an example for developing a mathematical model for load-bearing structures (Kachanov, Volkov \& Fatyhoy, 2009, Kachanov, Batyrev \& Volkov, 2011). The load-bearing structure of the roof of the Ice Sports Palace on Khodynskoye Field is a one-layer, reticle, guy shell made of 48 radial flexural-hard I-section threads delineated on the 198 $\mathrm{m}$ radius, ring cells consisting of I-section beams and tubular connections filling virtually all the roof cells. In fact, this is an inverted Shvedler Cupola, which is a discreet analogue of a guy shell with the elements resisting tension, compression, bending, and shear in three dimensions.

The roof shell has a circular outline with the external diameter of around $110 \mathrm{~m}$. The sag is $7.9 \mathrm{~m}$, or $1 / 14$ of the flight. The shell has a doubly connected contour comprised by an external composite ring with rectangular 1,200x1,600 $\mathrm{mm}$ cross-section, and an I-section central 
internal ring with $20 \mathrm{~m}$ diameter and $1,200 \mathrm{~mm}$ height. The external bearing ring rests on a ferroconcrete slab crowning the load-bearing structures of the stalls. The main supports of the shell are 'floating' to prevent the thrust transfer from the shell to the stalls. The three supports on the major diameters of the roof prevent it from the horizontal shift.

The load-bearing element of the roof is roofing profile put in a circular fashion on the load-bearing threads and attached to them by tapping screws. The roofing profile makes an orthotropic shell working jointly with the major reticle shell. The mathematical model has been designed on the Nastran calculation suite and includes a three-dimensional geometric layout of the structures, databases on the physical features of the construction materials and geometrical features of the cross-sections of the construction elements, databases on the loads and their design combinations. The three-dimensional geometric layout was built on the AutoCAD design suite and exported to the Nastran's Femap preprocessor in the DXF format. All the construction elements of the roof mesh (rings, hard threads and bracings) were modelled by lines, and the plate elements framing the internal ring were modelled by flat surfaces.

The end element mesh was superimposed on the geometric layout: the BEAM type rod end elements were used for the lines, and the PLATE type elements were used for the surfaces. The database on the physical features of the construction materials was generated based on the following data.

For steel:

- $E=2.1 \cdot 10^{6} \mathrm{kgf} / \mathrm{cm}^{2}-$ modulus of elasticity,

- $v=.3-$ Poisson ratio,

- $\rho=C \gamma / g=1.2 \cdot 7.85 \cdot 10^{-3} / 981=9.6 \cdot 10^{-6} \mathrm{kgf} \cdot \mathrm{sec}^{2} / \mathrm{cm}^{4}-$ density,

where $C=1.2$ - construction coefficient, $\gamma=7.85 \cdot 10^{-3} \mathrm{kgf} / \mathrm{cm}^{3}-$ bulk weight of steel, $\mathrm{g}=981 \mathrm{~cm} / \mathrm{sec}^{2}-$ free fall acceleration.

For concrete:

- $E=3 \cdot 10^{5} \mathrm{kgf} / \mathrm{cm}^{2}-$ modulus of elasticity,

- $v=.3-$ Poisson ratio,

- $\rho=C \gamma / g=1.1 \cdot 2.5 \cdot 10^{-3} / 981=2.8 \cdot 10^{-6} \mathrm{kgf} \cdot \mathrm{sec}^{2} / \mathrm{cm}^{4}-$ density.

A specialized component unit of the Nastran suite was used for designing the geometric features of the cross-sections of the construction elements.

The geometric layout and the end-element layout of the roof load-bearing structures were respectively imported and designed under the protocol in Table 1 . The titles of the construction elements correspond with the titles of dxf-files.

The lines and end elements with geometric features are represented by corresponding groups of numbers, which are in their turn arranged by layers. A structure like that when used for designing a roof mathematical model ensures convenient application of large databases in the future. 
Table 1. Protocol for Designing End-Element Layout of the Roof

\begin{tabular}{|c|c|c|c|c|c|}
\hline $\begin{array}{l}\text { Title of construc- } \\
\text { tion elements }\end{array}$ & \begin{tabular}{|}
$\begin{array}{c}\text { Average length } \\
\text { of end-element } \\
(\mathrm{cm})\end{array}$ \\
\end{tabular} & Line numbers & $\begin{array}{c}\text { End-element } \\
\text { numbers }\end{array}$ & $\begin{array}{c}\text { Geometric features } \\
\text { numbers }\end{array}$ & Layer numbers \\
\hline $\begin{array}{l}\text { Outer ring, ferro- } \\
\text { concrete filling }\end{array}$ & 42 & $1-144$ & $1-816$ & Prop. 1 & $\begin{array}{c}\text { Layer } 5 \\
\text { Koltso beton } \\
\end{array}$ \\
\hline $\begin{array}{l}\text { Outer ring, steel } \\
\text { form } \\
\end{array}$ & 42 & $1-144$ & $817-1632$ & Prop. 2 & $\begin{array}{c}\text { Layer } 6 \\
\text { Koltso steel }\end{array}$ \\
\hline \begin{tabular}{|c|} 
Outer ring supports \\
with gaps
\end{tabular} & 105 & $145-240$ & $1633-1728$ & Prop. 3 & $\begin{array}{c}\text { Layer } 3 \\
\text { GAP }\end{array}$ \\
\hline Hard threads 1 & 61 & $241-432$ & $1729-2688$ & Prop. 4 & \multirow{17}{*}{$\begin{array}{l}\text { Layer } 2 \\
\text { Pokrytie }\end{array}$} \\
\hline Hard threads 2 & 61 & $433-576$ & $2689-3456$ & Prop. 5 & \\
\hline Hard threads 3 & 61 & $577-720$ & $3457-4224$ & Prop. 6 & \\
\hline Hard threads 4 & 61 & $721-912$ & $4225-5232$ & Prop. 7 & \\
\hline Ring elements 1 & 90 & $913-960$ & $5233-5568$ & Prop. 8 & \\
\hline Ring elements 2 & 90 & $961-1008$ & $5569-5856$ & Prop. 9 & \\
\hline Ring elements 3 & 90 & $1009-1104$ & $5857-6384$ & Prop. 10 & \\
\hline Ring elements 4 & 80 & $1105-1200$ & $6385-6816$ & Prop. 11 & \\
\hline Ring elements 5 & 48 & $1201-1296$ & $6817-7248$ & Prop. 12 & \\
\hline Ring elements 56 & 40 & $1297-1344$ & $7249-7440$ & Prop. 13 & \\
\hline Bracings $\boldsymbol{a}$ & 110 & $1345-1392$ & $7441-7824$ & Prop. 14 & \\
\hline Bracings $\boldsymbol{\sigma}$ & 91 & $1393-1632$ & $7825-9504$ & Prop. 15 & \\
\hline Bracings $\boldsymbol{B}$ & 80 & $1633-1728$ & $9505-10320$ & Prop. 16 & \\
\hline Bracings 2 & 75 & $1729-1776$ & $10321-10512$ & Prop. 17 & \\
\hline Inner ring & 33 & $1777-1824$ & $10513-10704$ & Prop. 18 & \\
\hline Chords & 62 & $1825-1936$ & $10705-11088$ & Prop. 19 & \\
\hline Diagonal rods & 41 & $1937-2032$ & $11089-11472$ & Prop. 20 & \\
\hline $\begin{array}{l}\text { Inner ring rein- } \\
\text { forcement plates }\end{array}$ & & & $11473-12240$ & Prop. 21 & $\begin{array}{l}\text { Layer } 4 \\
\text { Plate }\end{array}$ \\
\hline $\begin{array}{l}\text { Rigid Inserts } \\
\text { Rigid }\end{array}$ & & & $12241-12272$ & & $\begin{array}{l}\text { Layer } 2 \\
\text { Pokrytie }\end{array}$ \\
\hline
\end{tabular}

To ensure the roof survivability if the outer ring fails (is damaged), 96 extra horizontal bearings are to be employed if the ring moves inside about $20 \mathrm{~mm}$. In the mathematical model, the elements are represented by the dedicated GAP type end elements with the gap of $20 \mathrm{~mm}$ and compressive stiffness of $\mathrm{C}_{\mathrm{e}}=2 \cdot 10^{6}$ and tension stiffness of $\mathrm{C}_{\mathrm{t}}=1 \cdot 10^{-4}$. The Nastran design software was used to calculate the gravity load of the roof load-bearing structures, including the roofing profile shell, based on the geometric and physical features of the construction materials. 
The test loads modeling the gravity load of the roof, the snow and technological load are calculated and applied to the roof bearing mesh as lumped masses at the ring and radial element intersection nodes. The dedicated MASS end-element type is used for this purpose (Fig.3).

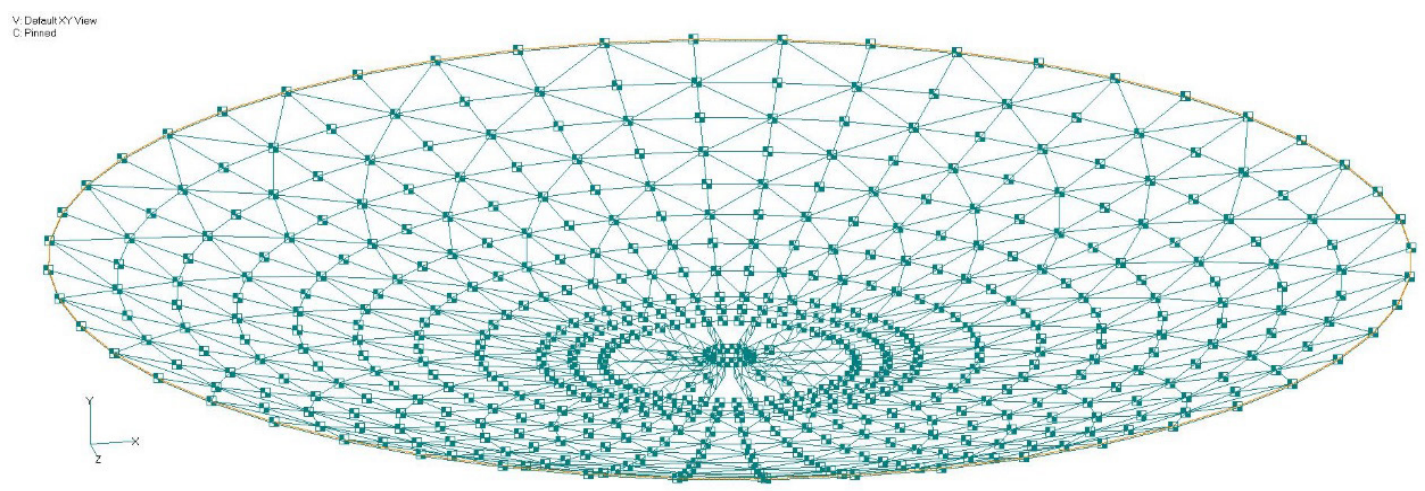

Figure 3. MASS-Type End-Element Layout

See Table 2 for the roof load intensity.

Table 2. Intensity of Loads on the Roof

\begin{tabular}{|c|c|c|c|}
\hline Load Type & $\begin{array}{c}\text { Design Load } \\
\mathrm{g}^{\mathrm{n}}\left(\mathrm{kgf} / \mathrm{m}^{2}\right)\end{array}$ & Load Effect Factor $\gamma_{\mathrm{f}}$ & $\begin{array}{c}\text { Design Load } \\
\mathrm{g}\left(\mathrm{kgf} / \mathrm{m}^{2}\right)\end{array}$ \\
\hline Insulating roof layers & 65 & 1.1 & 72 \\
\hline Technological & 10 & 1.1 & 11 \\
\hline Subtotal load & 75 & 1.1 & 83 \\
\hline Snow load & 140 & 1.43 & 200 \\
\hline Total, snow included & 215 & 1.316 & 283 \\
\hline
\end{tabular}

The data in the table is based on the design materials specified according to the results of an on-site survey. Considering the roof symmetry, it is enough to calculate the values of node masses located on one radial hard thread. Figure 4 shows the sizes of load areas $\mathrm{A}\left(\mathrm{m}^{2}\right)$ related to corresponding nodes, where Num shows the numbers of the nodes on the hard thread, starting with the outer ring and going to the center, while Table 3 shows standard and design values of node masses.

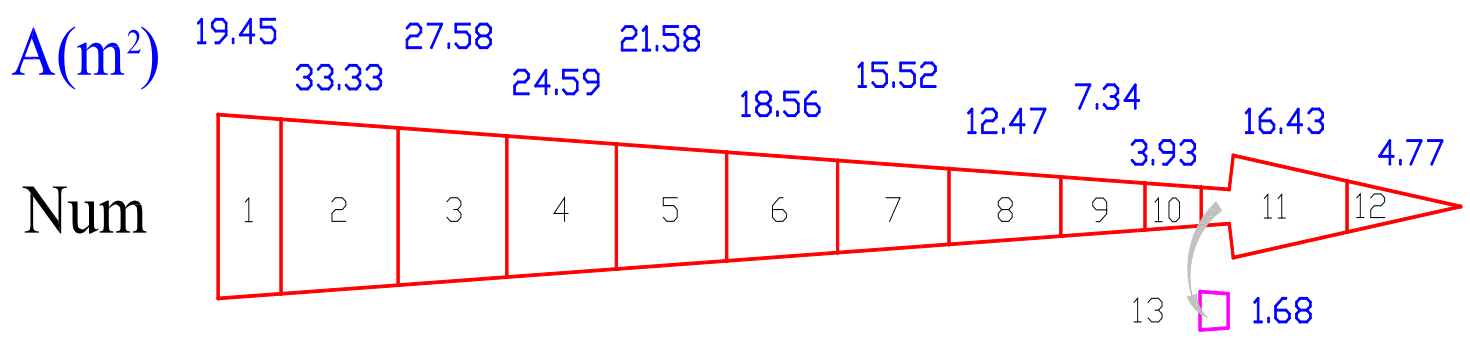

Figure 4. Load Areas for Calculating Masses. 
Table 3. Standard $\left(\mathrm{m}^{\mathrm{n}}\right)$ and Design (m) Values of Node Masses $\left(\mathrm{kgf} \cdot \mathrm{sec}^{2} / \mathrm{cm}^{4}\right)$

\begin{tabular}{|c|c|c|c|c|c|c|}
\hline \multirow{2}{*}{$\begin{array}{l}\text { \# of node } \\
\text { (load area) }\end{array}$} & \multirow{2}{*}{ PROP } & \multirow{2}{*}{$\begin{array}{c}\text { Load } \\
\text { area } \\
\text { A }\left(\mathcal{M}^{2}\right)\end{array}$} & \multicolumn{2}{|c|}{ Summer (no snow) } & \multicolumn{2}{|c|}{ Winter (with snow) } \\
\hline & & & $\mathrm{m}^{\mathrm{n}}=\mathrm{A}_{\mathrm{i}} \cdot 75 / 981$ & $m=A_{i} 83 / 981$ & $\mathrm{~m}^{\mathrm{n}}=\mathrm{A}_{\mathrm{i}} \cdot 215 / 981$ & $\mathrm{~m}=\mathrm{A}_{\mathrm{i}} 283 / 981$ \\
\hline 1 & 2 & 9.45 & 1.487 & 1.646 & 4.263 & 5.611 \\
\hline 2 & 3 & 33.33 & 2.548 & 2.820 & 7.300 & 9.615 \\
\hline 3 & 4 & 27.58 & 2.109 & 2.333 & 6.045 & 7.956 \\
\hline 4 & 5 & 24.59 & 1.880 & 2.080 & 5.389 & 7.094 \\
\hline 5 & 6 & 21.58 & 1.650 & 1.826 & 4.730 & 6.225 \\
\hline 6 & 7 & 18.56 & 1.419 & 1.570 & 4.068 & 5.354 \\
\hline 7 & 8 & 15.52 & 1.187 & 1.313 & 3.401 & 4.477 \\
\hline 8 & 9 & 12.47 & 0.953 & 1.055 & 2.733 & 3.597 \\
\hline 9 & 0 & 7.34 & 0.561 & 0.621 & 1.609 & 2.117 \\
\hline 10 & 1 & 3.93 & 0.300 & 0.333 & 0.861 & 1.134 \\
\hline 11 & 2 & 16.43 & 1.256 & 1.390 & 3.600 & 4.740 \\
\hline 12 & 3 & 4.77 & 0.365 & 0.404 & 1.045 & 1.376 \\
\hline 13 & 34 & 1.68 & 0.128 & 0.142 & 0.368 & 0.485 \\
\hline 14 & 5 & Techno & logical platform & $\begin{array}{l}\text { ith the weight } \\
\sec ^{2} / \mathrm{cr}\end{array}$ & 8 tf. $m=8000 / 4$ & $81=2.0387 \mathrm{kgf}$ \\
\hline 15 & 6 & & & $\begin{array}{l}\text { ght of } \cdot 10 \text { tf. } \mathrm{m} \\
\text { (only for th }\end{array}$ & $\begin{array}{l}10000 / 4 / 981=2 \\
\text { Y axis) }\end{array}$ & $48 \mathrm{kgf} \cdot \mathrm{sec}^{2} / \mathrm{cm}^{4}$ \\
\hline
\end{tabular}

See Tables 4 and 5 below for the results of statistic calculations determining the thresholds for normal, pre-fault and unacceptable exploitation in summer and winter, based on the accepted mathematical model for the behaviour of the ISP roof.

Table 4. Criteria for Technical Condition of the Roof Depending on the Controlled Rings Rotation Angles in the 'Summer' Exploitation Period.

\begin{tabular}{|c|c|c|c|c|c|c|}
\hline \multirow{2}{*}{$\begin{array}{c}\text { Roof Ring } \\
\text { Number }\end{array}$} & $\begin{array}{c}\text { Normal exploitation threshold } \\
\text { (Normal mode) }\end{array}$ & \multicolumn{2}{c|}{$\begin{array}{c}\text { Pre-fault exploitation } \\
\text { threshold (Caution mode) }\end{array}$} & \multicolumn{2}{|c|}{$\begin{array}{c}\text { Unacceptable exploitation } \\
\text { threshold (Danger mode) }\end{array}$} \\
\cline { 2 - 7 } & $\begin{array}{c}\text { Movements } \\
(\mathrm{mm})\end{array}$ & $\begin{array}{c}\text { Rotation An- } \\
\text { gle (radian) }\end{array}$ & $\begin{array}{c}\text { Movements } \\
(\mathrm{mm})\end{array}$ & $\begin{array}{c}\text { Rotation An- } \\
\text { gle (radian) }\end{array}$ & $\begin{array}{c}\text { Movements } \\
(\mathrm{mm})\end{array}$ & $\begin{array}{c}\text { Rotation An- } \\
\text { gle (radian) }\end{array}$ \\
\hline 1 & 0 & 0.00391 & 0 & 0.00407 & 0 & 0.00423 \\
\hline 2 & 34 & 0.0018 & 35.7 & 0.00191 & 37.4 & 0.00202 \\
\hline 3 & 44.3 & 0.00025 & 46.4 & 0.00034 & 48.5 & 0.00041 \\
\hline 4 & 53.9 & 0.00025 & 54.7 & 0.00032 & 55.5 & 0.00039 \\
\hline
\end{tabular}

The calculations shown in the table above are based on the standard gravity loads generated by the roof load-bearing and enclosure structures, technological loads from engineering networks, flying bridges, the central technological platform and the mediacube. 
Table 5. Criteria for Technical Condition of the Roof Depending on the Controlled Rings Rotation Angles in the 'Winter' Exploitation Period (with Snow Load)

\begin{tabular}{|c|c|c|c|c|c|c|}
\hline \multirow{2}{*}{$\begin{array}{c}\text { Roof Ring } \\
\text { Number }\end{array}$} & \multicolumn{2}{|c|}{$\begin{array}{c}\text { Normal exploitation threshold } \\
\text { (Normal mode) }\end{array}$} & \multicolumn{2}{c|}{$\begin{array}{c}\text { Pre-fault exploitation } \\
\text { threshold (Caution mode) }\end{array}$} & \multicolumn{2}{c|}{$\begin{array}{c}\text { Unacceptable exploitation } \\
\text { threshold (Danger mode) }\end{array}$} \\
\cline { 2 - 7 } & Movements $(\mathrm{mm})$ & $\begin{array}{c}\text { Rotation } \\
\text { Angle }(\text { radian }\end{array}$ & $\begin{array}{c}\text { Movements } \\
(\mathrm{mm})\end{array}$ & $\begin{array}{c}\text { Rotation } \\
\text { Angle (radian) }\end{array}$ & Movements (mm) & $\begin{array}{c}\text { Rotation } \\
\text { Angle (radian) }\end{array}$ \\
\hline 1 & 0 & 0.00563 & 0 & 0.00709 & 0 & 0.00855 \\
\hline 2 & 54.1 & 0.00331 & 70.8 & 0.00454 & 87.5 & 0.00577 \\
\hline 3 & 75.2 & 0.00059 & 100.6 & 0.00074 & 126 & 0.00089 \\
\hline 4 & 75.8 & 0.00053 & 93.9 & 0.00122 & 112 & 0.00191 \\
\hline
\end{tabular}

The figures in Table 5 are based on the design values of the permanent loads mentioned above, as well as the design snow load $\left(200 \mathrm{kgf} / \mathrm{m}^{2}\right)$ applied to half of the roof and all the surface inside the inner ring. A similar distribution of snow on the roof was observed in winter 2007. The snow redistribution on the roof was caused by its gradual slide from the peripheral area to the center. It is obvious that the distribution of snow on the roof like that is not strictly justified and is used here with a certain safety margin given the lack of more precise data.

The ESMS software suite registers changes based on the criteria calculated in the tables above. The technical condition criteria for the ISP roof load-bearing structures can be developed on the aforementioned basics to establish a conclusion-drawing procedure for a monitoring stage of the technical condition of the facility engineering structures and determine a decision-making procedure to ensure a safe technical condition for the facility engineering structures.

The 'traffic lights' may be used as danger indicators and the integral characteristics like movements, shapes and oscillation frequencies of the construction may be considered to 'switch on': a) the green light, when the values monitored for these characteristics are within the standard impact scope. This is a normal exploitation condition for the construction; $b$ ) the red light, when the monitored values reach or exceed the limits for design impact. This condition bans further construction exploitation; c) the yellow light, when the monitored values are between the abovementioned ones. This condition warns about a significant danger forthcoming. It is expedient to discover the reason quickly, eliminate it if possible, or take preemptive measures.

\section{References}

1. Volkov, A. A., Sedov, A. V., \& Chelyshkov, P. D., Zinkov, A. (2010). Automation tasks in the task of energy conservation. Building automation, (3-5), 25.

2. Cvetkovic, V., \& Martinović, J. (2021). Innovative solutions for flood risk management. International Journal of Disaster Risk Management, 2(2), 71-100.

3. Ginzburg A. (2013). Queuing Systems in Management Construction. Applied Mechanics and Materials, Vols. 405-408, 3352-3355.

4. Ginzburg A., Khripushin A. (2013). Risk Management in oil refinery construction projects. Applied Mechanics and Materials, Vols. 411-414, 2313-2316.

5. Ginzburg A., Ryzhkova A. (2014). Accounting "pure" risks in early stage of investment in construction projects with energy efficient technologies in use. Applied Mechanics and Materials, Vols. 672-674, 2221-2224. 
6. Ginzburg A., Skiba A. (2014). Creating an urban area planning design based on the theory of fuzzy logic. Applied Mechanics and Materials, Vols. 584-586, 507-511.

7. Ginzburg A.V., Ryzhkova A.I. (2014). Intensification development of energy efficient technologies, taking into account the organizational and technological reliability. M. Scientific Review 7, 276-280.

8. Kachanov, S., Mahutov, N., Taranov, S. (2010). Optimizing Measures Taken for Better Protection of Facilities Critically Important for the National Security of the Russian Federation and Population Against the Technogenic and Natural Threats, and Terrorism. Civil Safety Technologies. Journal of Science and Technology, Vol. 7, №1-2

9. Kachanov, S., Nigmetov, G. (2008). Monitoring of Territories, Buildings and Constructions for Improving the Reliability of Results for Independent Risk Assessment. Civil Safety Technologies. Journal of Science and Technology Issue 3 (17).

10. Kachanov, S., Volkov, O., Fatyhov, R. (2009). Computer Model for Monitoring Stress and Strain Behavior of Load-Bearing Structures in Technically Complex and Unique Facilities (Using the Ice Sports Palace on the Khodynskoye Field in Moscow as an Example). Civil Safety Technologies. Journal of Science and Technology, Vol. 6, №3-4.

11. Kachanov,S., Batyrev, V., Volkov. O. (2011). Technologies for Building Structured Monitoring and Management Systems for Engineering Systems of Buildings and Constructions. Novosibirsk: Alfa-Porte Ltd., 269.

12. Rico, G. (2019). School-Community Collaboration: Disaster Preparedness towards Building Resilient Communities. International Journal of Disaster Risk Management, 1(2), 45-61. 